\title{
Reconstructing vegetation history of the Olorgesailie Basin during the Middle to Late Pleistocene using phytolith data
}

Rahab N. Kinyanjui ${ }^{1}$

Department of Earth Sciences, National Museums of Kenya, Nairobi, Kenya

Michael Meadows ${ }^{2}$

Department of Environmental and Geographical Science, University of Cape Town, Rondebosch, South Africa

Lindsey Gillson

Plant Conservation Unit, Botany Department, University of Cape Town, Rondebosch, South Africa

Marion. K. Bamford

The Evolutionary Studies Institute, University of the Witwatersrand, Johannesburg, South Africa

Anna K. Behrensmeyer

Department of Paleobiology, Smithsonian Institution, Washington, DC USA

Richard Potts

Human Origins Program, Smithsonian Institution, Washington, DC USA

\begin{abstract}
The Olorgesailie basin, located in the East African Rift System (EARS), southern Kenya $\left(1.5-1.6^{\circ} \mathrm{S}, 36.4-36.5^{\circ} \mathrm{E}, 940-1040 \mathrm{~m}\right.$ asl), is an important site for palaeoanthropological, palaeontological and geological research, with sediments dating back more than $1 \mathrm{Ma}$. Little is known about the palaeovegetation and palaeoenvironmental context of this important site and how this varied through space and time. Here we use phytolith data to reconstruct the vegetation history through the Middle and Late Pleistocene (c. $670 \mathrm{ka}$ to $c$. $64 \mathrm{ka}$ ). The analysis of 24 samples from

\footnotetext{
${ }^{1}$ Other affiliation: Department of Environmental \& Geographical Science, University of Cape Town, South Africa; School of Geographical Sciences, East China Normal University, Shanghai, China; and College of Geography and Environmental Sciences, Zhejiang Normal University, Jinhua, China

${ }^{2}$ Other affiliation: School of Geographic Sciences, East China Normal University, Shanghai, China; and College of Geography and Environmental Sciences, Zhejiang Normal University, China
} 
palaeosols within the Olorgesailie and Oltulelei Formations uses diagnostic phytoliths to plot relative phytolith abundance diagrams documenting temporal and spatial vegetation variations. We use three phytolith indices (climate index, aridity index and tree density index) to estimate temperature, precipitation, and vegetation structure from sediments that are well-constrained chronologically by ${ }^{40} \mathrm{Ar} /{ }^{39} \mathrm{Ar}$ dating. Spatial vegetation variation is captured through examining phytoliths from three distinct localities (Loc. OLT, Loc. B and Loc. G) over a distance of about $5 \mathrm{~km}$. Results suggest that local vegetation changes approximately correspond with stratigraphic units. Phytolith indices reflect warm and moist conditions $c .670 \mathrm{ka}$, with cool and dry conditions from $c$. $650 \mathrm{ka}$ during which time riparian and a variety of other habitats were present. An unconformity, which extends over c. 180,000 years (500 to $320 \mathrm{ka}$ ), is interpreted as largely caused by tectonic processes coupled with precipitation variability. A shift from woody vegetation to $\mathrm{C}_{4}$ grasslands is evident following the unconformity, and riparian habitats were again present. Considerable climate variability is apparent thereafter, with inconsistent precipitation conditions until c. $220 \mathrm{ka}$ when more stable and moist conditions set in until c. $64 \mathrm{ka}$. The study documents vegetation dynamics directly associated with the Middle to Late Pleistocene palaeontological and archaeological record of Olorgesailie.

\subsection{INTRODUCTION}

East Africa is well known for its archive of human evolutionary history and the long-term history of ecological interactions between faunal and floral species and their environments (Bobe and Behrensmeyer 2002; Potts 1998). Tectonic processes created the episodic fossilization and preservation of records of ancient life in the East Africa Rift system (EARS) (Brown and Feibel 1991; Feibel 1999; Campsiano and Feibel 2008). Extensively collected and documented EARS fossils have addressed a variety of research questions including human and faunal evolutionary history, extinction and speciation events, species-environment interactions and the impact of climate change on past ecosystems (Bobe and Behrensmeyer 2004; deMenocal 2004; Feakins et al. 2007; Lepre et al. 2007; Potts and Faith 2015; Trauth et al. 2007).

Previous studies suggest that African climate and vegetation cover have been highly variable since the early Pliocene, oscillating from warm and humid to cool and dry episodes that can be correlated with orbital oscillations (Cerling et al. 2011; deMenocal 1995; Feakins et al. 2007; Lepre et al. 2007; Potts 2013; Trauth et al. 2007). These oscillations resulted in habitats that varied between woodland, wooded grassland and open grassland. Such vegetation dynamics influenced hominin diets and ecomorphology in the region, such as in the Awash and Olduvai basins (Albert et al. 2009; Ashley et al. 2010a; Bamford et al. 2006; Basell 2007; Cerling et al. 2010; White et al. 2010; WoldeGabriel et al. 2009).

In the Olorgesailie basin, vegetation cover has previously been reconstructed in only a single palaeosol dated $c .1 \mathrm{Ma}$, based on carbon isotope data and faunal remains (Sikes et al. 1999). The rich palaeontological, archaeological and geological data published from the basin have otherwise lacked a parallel body of evidence on vegetation cover and how its structure changed over time and across the landscape. Initial steps geared to reconstructing the vegetation cover and structure were hindered by poor preservation of fossil pollen and other organic plant remains due to high salinity in the basin (Livingstone and Mworia 1999). A subsequent feasibility study showed the potential for using fossil phytoliths to reconstruct vegetation cover and structure during the Middle to Late Pleistocene of the basin (Kinyanjui 2012).

Phytoliths are plant silica bodies that form when silica is deposited within and around plants cells during evapotranspiration, resulting in cell casts/replicas that are morphologically distinct. The silica cells are preserved in the soils after the decomposition of the parent plants (Mulholland and Rapp 1992; Piperno 1988; 2006). They are inorganic in nature, preserve well in a variety of depositional regimes, and are particularly useful because of good preservation in 
regions where organic plant remains are susceptible to oxidation and thus less likely to accumulate (Piperno 2006). Phytolith research in East Africa has gained popularity as a reliable proxy for reconstructing past vegetation cover (Alexandre et al. 1997; Bremond et al. 2005a, b; 2008; Fredlund and Tieszen 1994) geared toward understanding past environments (Albert et al. 2012; 2015; Bamford et al. 2006; Barboni et al. 2009; 2010; Estaban et al. 2020; Kinyanjui 2013). In addition, phytolith indices can be used to determine changes in precipitation, vegetation structure dynamics, and provide coarse estimates of variations in temperature through time (Aleman et al., 2008; Alexandre et al. 1997; Bremond et al. 2008; Fredlund and Tieszen 1997).

This paper presents phytolith data from the upper Olorgesailie Formation dated between c. $670 \mathrm{ka}$ and $500 \mathrm{ka}$ (Deino et al. 2018; Isaac 1978) and the Oltulelei Formation dated between c. $320 \mathrm{ka}$ to $c .36 \mathrm{ka}$ (Behrensmeyer et al. 2018; Deino et al. 2018). The stratigraphic sequence covers a significant period when hominins acquired new adaptive strategies associated with changing environments, which also coincided with replacement of mega-herbivore species by smaller herbivore taxa in the basin (Potts 1998; Potts and Faith 2015; Potts et al. 2018) associated with climate and local tectonic processes (Behrensmeyer et al. 2018; Potts et al. 2020).

\subsection{STUDY SITE: OLORGESAILIE BASIN}

The Olorgesailie basin is located in the southern part of the Kenyan Rift Valley $\left(1^{\circ} 3^{\prime} \mathrm{S}\right.$ and $36^{\circ} 2^{\prime} \mathrm{E}$; 940-1040 m asl) (Figure 1). It is renowned for its high concentration of Acheulean hand axes dated c. 1.2 Ma to 500 ka (Deino and Potts 1990; Isaac 1977; 1978; Potts 1989; Potts et al. 1999). The basin lies near the southern end of the Eastern Arc of the East African Rift System (EARS). To the south it is bounded by lavas associated with Mt. Olorgesailie, an extinct Pliocene-Early Pleistocene age volcano, while to the north, east and west the basin is delimited by faulted ridges of trachytes, phonolites, and basalts extruded during the Plio-Pleistocene (Baker and Mitchell 1976; Isaac 1978; Shackleton 1978). The basin's present drainage system flows from north to south following the slope of the rift floor (Baker 1958), and from east to west along the northern foothills of Mt. Olorgesailie, although tectonic movements and volcanism altered these drainage patterns in the past (Behrensmeyer et al. 2002; 2018). The main outcrops of the basin north of Mt. Olorgesailie cover an area of c. $65 \mathrm{~km}^{2}$.

\subsubsection{Present-day climate and vegetation}

Climate in the Olorgesailie region is largely controlled by the annual north-south oscillation of the Intertropical Convergence Zone (ITCZ) (Hills 1978; Kenworthy 1966; Nicholson 1996) resulting in two distinct rainy seasons: (i) long rains from March to June, and (ii) short rains from October to December (Asani and Kinuthia 1979; Griffiths 1958; 1972; Nicholson 1996; Sansom 1954). There are, however, anomalies in the rainfall pattern influenced by local topography. In this regard, the southern Kenya Rift Valley receives variable mean annual rainfall, for example $1000-1500 \mathrm{~mm}$ in the rift-margin highlands and $250-500 \mathrm{~mm}$ in the rift-axis lowlands (Griffiths 1972; Mutai and Ward 2000). The mean annual rainfall around the Olorgesailie basin is less than $500 \mathrm{~mm}$ which, combined with an evapo-transpiration rate exceeding $2400 \mathrm{~mm} /$ year, results in the negative hydrological balance responsible for the semi-arid condition of the basin (Damnati and Taieb 1995).

Vegetation in the Olorgesailie basin today is classified as a semi-arid variant of CommiphoraAcacia bushland (White 1983) or as a Northern Acacia-Commiphora bushland (WWF Ecoregions) (Figure 1). The dominant woody species include Acacia tortilis (Forssk.) Hayne, $A$. senegal (L.) Willd., A. mellifera (Vahl)Benth, (Figure 2B), Commiphora africana (A. Rich) Engl., C. campestris Engl., C. samharensis Schweinf., C. schimperi (O. Berg) Engl. Terminalia sp., Balanites spp., Grewia bicolor Juss., G. villosa Willd., Boscia coriacea Pax, (Figure 2B) 


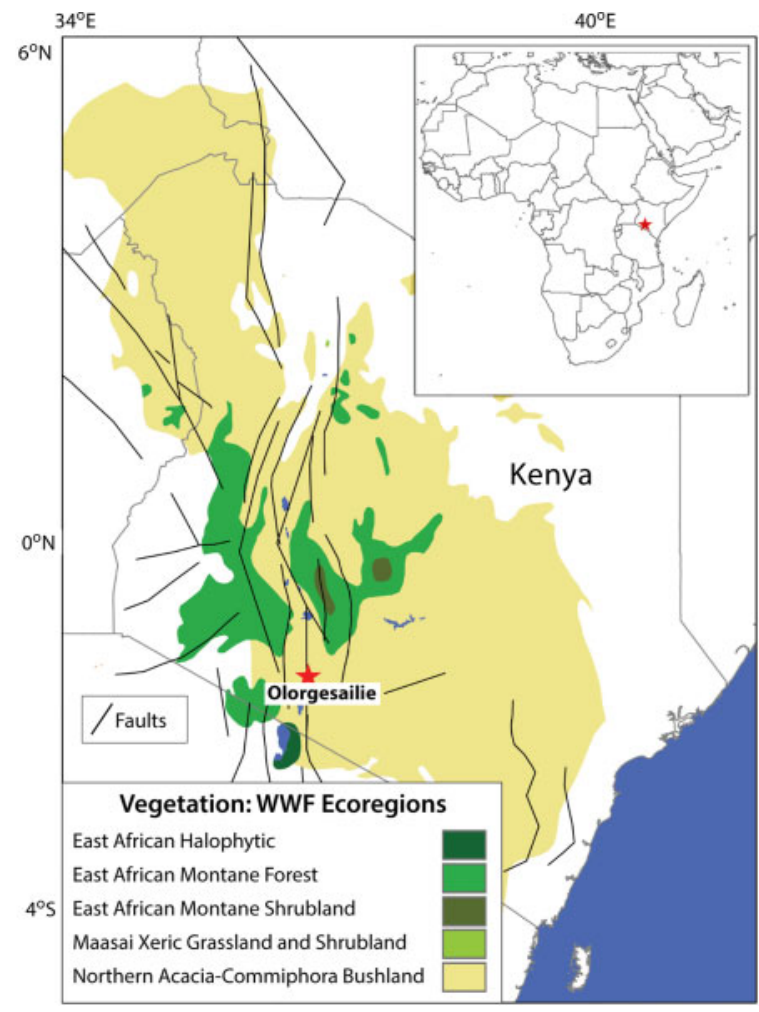

Figure 1. Map showing the location of the Olorgesailie basin and WWF vegetation designated ecoregions (White 1983).

and Salvadora persica L. The shrub component comprises Sericocomopsis hildebrandtii Schinz, Barleria sp., Aerva sp. and Indigofera sp. Most of the trees are deciduous and are in leaf during and after rains (Livingstone and Mworia-Maitima 1999; Mworia et al. 1988). Grasslands are $\mathrm{C}_{4}$ dominated, mostly Chloridoideae family such as Chloris roxburghiana Schult., Dactyloctenium bogdanii S.M Phillips, Eragrostis cilianesis (All.) F.T. Hubb., Tetrapogon cenchriformis (A. Rich.) W.D Clayton, Sporobolus jacquemontii Kunth. and Brachyachne spp. (Livingstone and Mworia-Maitima 1999; Mworia et al. 1988). Elements of riverine gallery forest are also present along the seasonal river channels (lagas); they include Syzygium cordatum Krauss, S. guineense (Willd.) DC., Delonix elata (L.) Gamble and Terminalia spp., while Kyllinga alba Nees and K. welwitschii are $\mathrm{C}_{4}$ sedges common in the floodplains (Livingstone and Mworia-Maitima 1999; Mworia et al. 1988).

\subsubsection{Geoarchaeology}

Current lithostratigraphic description distinguishes two units: the Olorgesailie and Oltulelei Formations (Behrensmeyer et al. 2002; 2018; Isaac 1978; Shackleton 1978), dated primarily by the single-crystal ${ }^{40} \mathrm{Ar} /{ }^{39} \mathrm{Ar}$ method (Behrensmeyer et al. 2018; Deino and Potts 1990; 1992; Deino et al. 2018; Potts et al. 2018). 

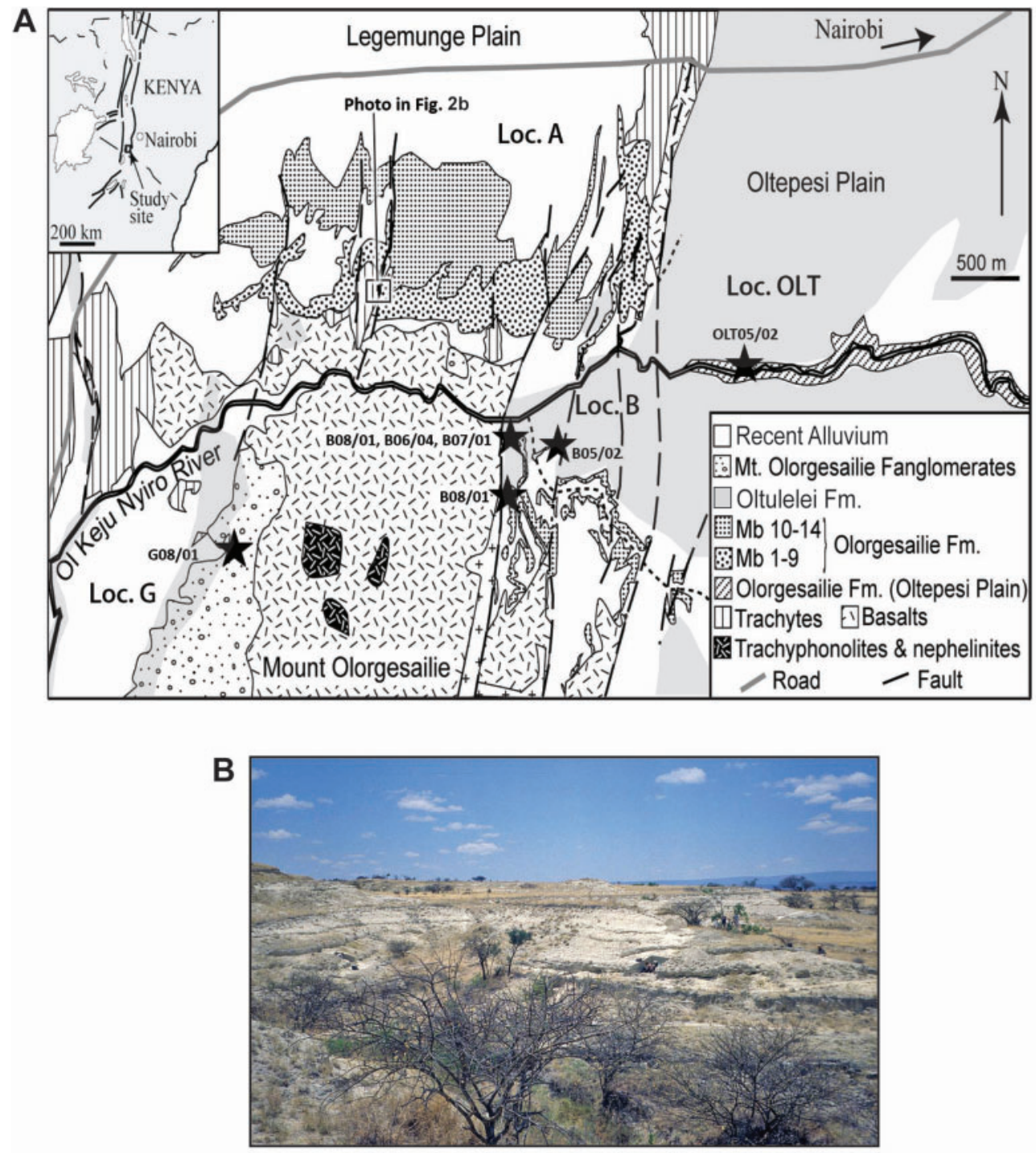

Figure 2. (A) Map showing Olorgesailie basin, localities, geo-trenches (marked with star) and the basin's geology. (B) Acacia melliferae and Boscia coriaceae visible in the photograph are among the dominant woody species in the basin.

\subsubsection{Olorgesailie formation}

These are deposits comprising lacustrine, wetland/swampy, fluvial and colluvial sediments forming a composite thickness of $c .80 \mathrm{~m}$ (Behrensmeyer et al. 2002). There are fourteen members (Isaac 1978; Shackleton 1978) with the base of the oldest member (Member 1) dated c. 1.2 Ma and the youngest Member (Member 14) c. $499 \mathrm{ka}$ (Behrensmeyer et al. 2002; Deino and Potts 1990, 1992; Deino et al. 2018). Erosion and excavations have exposed a rich archaeological record including Acheulean stone artifacts associated with extinct mammals, butchery sites and 


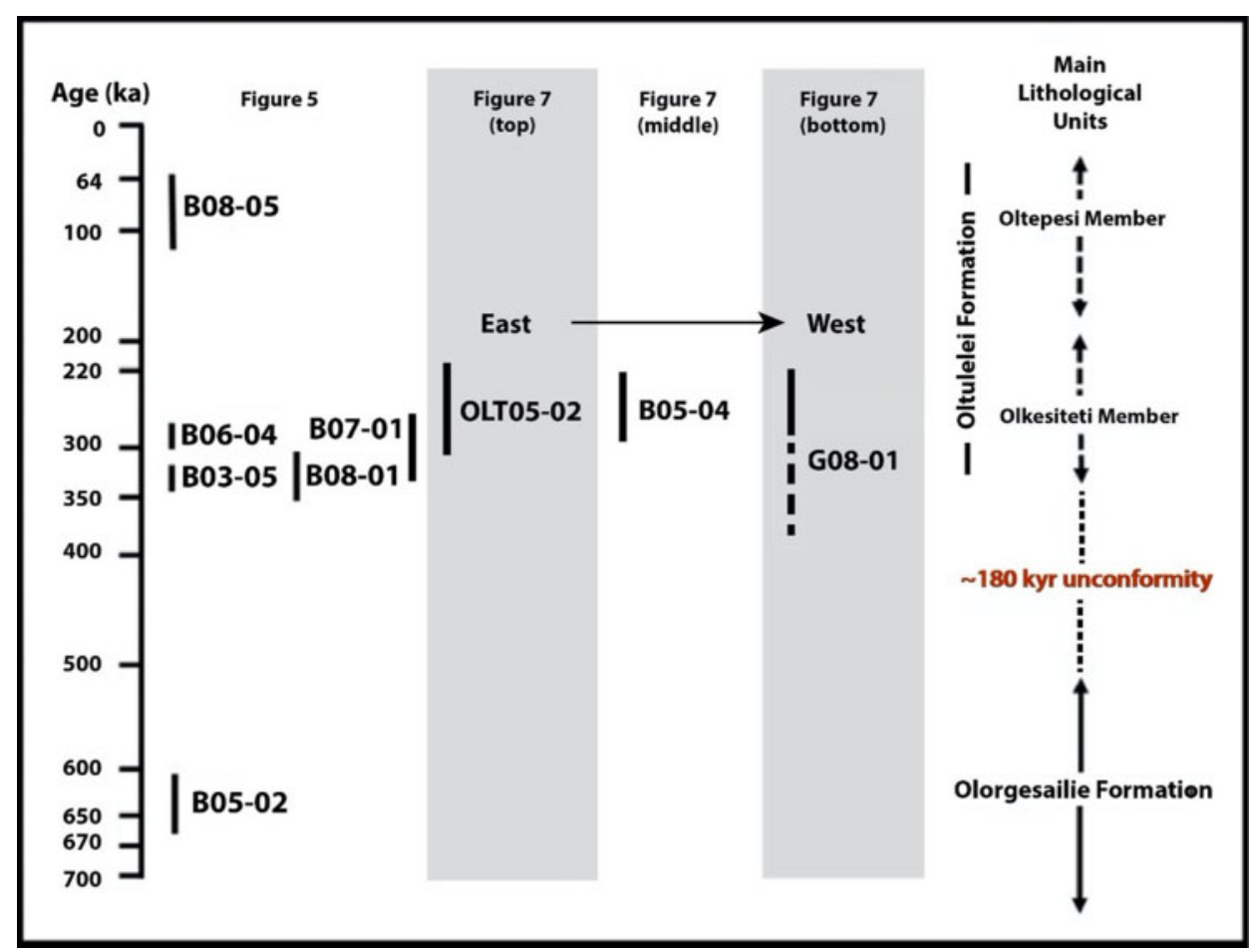

Figure 3. Schematic diagram showing lithostratigraphic/age relationship between sections.

hominin remains of Homo erectus (Potts 1994; Potts et al. 1999; 2004). Stable isotope data suggest vegetation structure around $1 \mathrm{Ma}$ was predominantly $\mathrm{C}_{4}$ grasslands (Sikes et al. 1999).

\subsubsection{Oltulelei formation}

These are younger deposits that overlie the Olorgesailie Formation, dated between c. $320 \mathrm{ka}$ and c. $36 \mathrm{ka}$ (Figure 3 ). The sediments rest on a major erosional unconformity, representing a hiatus of c. 180,000 years (Behrensmeyer et al. 2002; 2018; Deino et al. 2018) and consist of colluvial, alluvial, freshwater and saline lake deposits preserved in a series of erosional and channel filling regimes (Behrensmeyer et al. 2002; 2007; 2018). There are three successive members; Olkesiteti (c. 320-190 ka), Oltepesi (c. 190-50 ka) and Tinga (c. 50-36 ka) (Behrensmeyer et al. 2018; Deino et al. 2018). Exposures of these sediments have yielded stone tools of Middle Stone Age (MSA) technology and vertebrate fossils (Brooks et al. 2018; Potts et al. 2018).

\subsection{METHODS}

\subsubsection{Laboratory methods, microscopy and identification}

Phytolith extraction followed Albert's (1999) protocol with additional Acid Insoluble Fraction (AIF) steps (Mercader et al. 2010). All samples reached the minimum of 250 phytoliths counted for inclusion in the analysis, of these all but three samples yielded $>500$ phytoliths. Phytoliths 


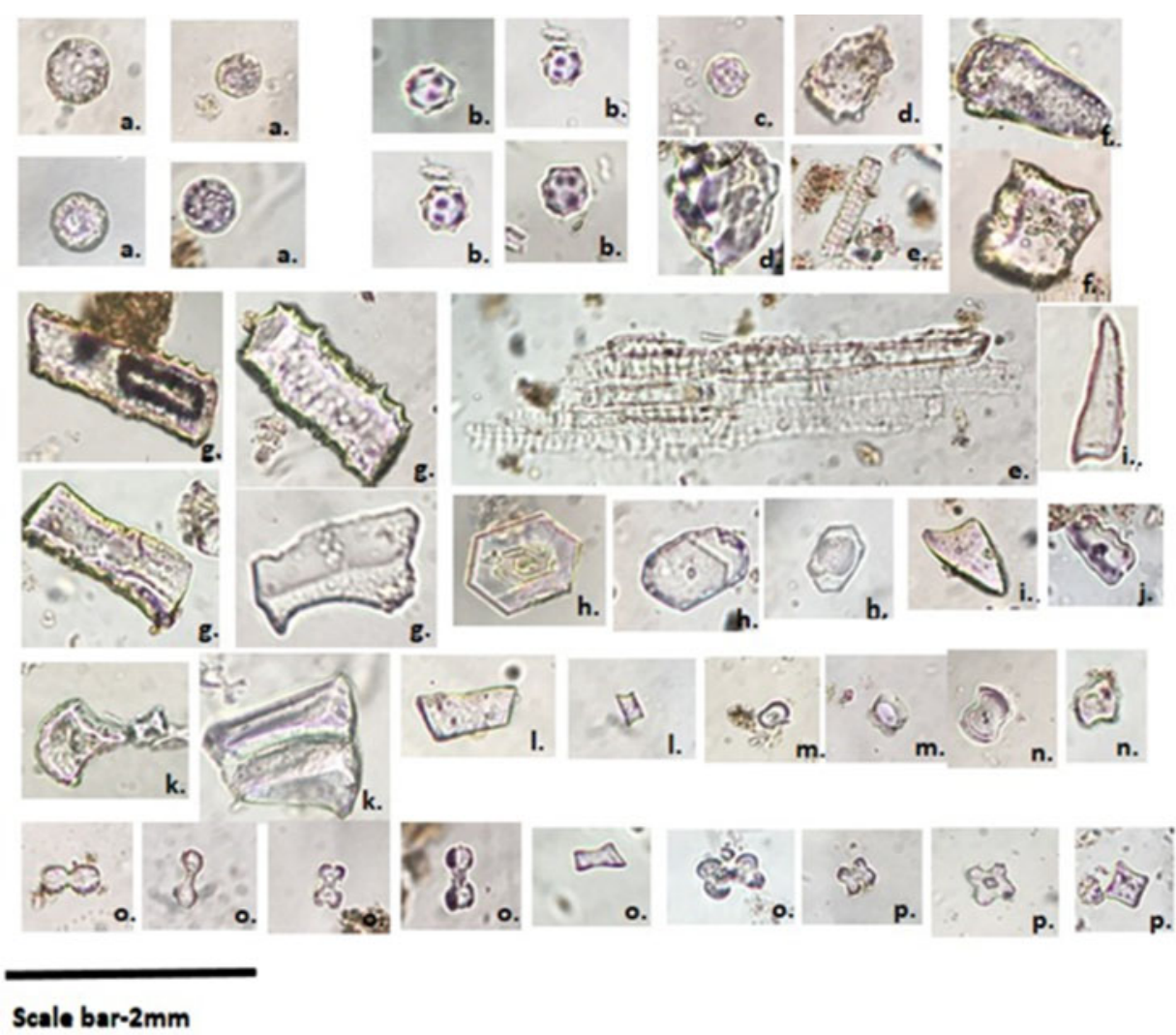

Figure 4. Micro-photographs of key fossil phytolith morphotypes identified. (a) Globular granulate, (b) globular echinate (Palm phytoliths), (c) Globular echinate (d) Globular verrucate, (e) Tracheid types, (f) Blocky types, (g) Sclereid bodies, (h) Achene (sedge phytoliths), (i) Scutiform/trichome types, (j) Crenate type, (k) Bulliform types, (l) Trapeziforms, $(\mathrm{m})$ rondels, $(\mathrm{n})$ saddles, (o) bilobates, $(\mathrm{p})$ crosses.

were identified at $400 \times$ magnification using an Olympus BX52 light microscope. Microphotographs were taken and viewed using image processing software; Image-Pros plus 5.1 and Infinity Capture 2. Images were stored as TIFF/JPEG files.

Morphological description and classification were based on phytolith shape and size based on the International Codes for Phytolith Nomenclature (ICPN) (Madella et al. 2005), while additional literature was consulted for specific taxa. Grass short cell phytoliths (GSCPs) assignments were based largely on the following studies (Barboni and Bremond 2009; Bremond et al. 2008; Esteban et al. 2016; Mercader et al. 2010; Neumann et al. 2009; 2017; Novello et al. 2012; Piperno 2006; Rossouw 2009; Strömberg 2004; Twiss 1992; Twiss et al. 1969), Woody (tree and shrub) (Albert and Weiner 2001; Mercader et al. 2009; Neumann et al. 2009; Piperno 2006; Runge 1999; Strömberg 2004) and Palm phytoliths (Figures 4b) (Albert et al. 2009; Ashley et al. 2010b; Neumann et al. 2009), Cyperaceae morphotypes (Honaine et al. 2006; Ollendorf 1992; Piperno 2006; Strömberg 2004), while the non-diagnostic types (trichomes, bulliforms, elongates) followed (Albert and Weiner 2001; Mercader et al. 2009; Neumann et al. 2009; Piperno 2006; Runge 1999; Strömberg 2004) (see Table 1). 
Table 1. Summary of the diagnostic morphotypes used to identify various taxa presented herein.

\begin{tabular}{|c|c|c|c|}
\hline Major Taxa & $\begin{array}{l}\text { Diagnostic } \\
\text { morphotype (s) }\end{array}$ & $\begin{array}{l}\text { Morphotype } \\
\text { description }\end{array}$ & $\begin{array}{l}\text { Comparable } \\
\text { references }\end{array}$ \\
\hline istidoideae & $\begin{array}{l}\text { - Bilobate convex } \\
\text { outer margin long } \\
\text { shaft. }\end{array}$ & $\begin{array}{l}\text { - Bilobate with rounded } \\
\text { lobes and long shaft } \\
(>10 \mu \mathrm{m}) \text {. }\end{array}$ & $\begin{array}{l}\text { Piperno and Pearsall } \\
\text { 1998; Piperno 2006; } \\
\text { Neumann et al., 2009. }\end{array}$ \\
\hline Panicoideae & $\begin{array}{l}\text { - Bilobates panicoid } \\
\text { type. } \\
\text { - Bilobates concave } \\
\text { outer margin } \\
\text { long/short shaft. } \\
\text { - Bilobates convex } \\
\text { outer margin outer } \\
\text { margin short shaft. } \\
\text { - Quadra-lobates/ } \\
\text { crosses. }\end{array}$ & $\begin{array}{l}\text { - Bilobate that is } \\
\text { symmetrical, with } \\
\text { rounded lobes. } \\
\text { Shaft }<10 \mu \mathrm{m}) \text {. } \\
\text { - Bilobates with lobes } \\
\text { curving inwards with } \\
\text { either long shaft } \\
(>10 \mu \mathrm{m}) \text { or short } \\
\text { shaft }(<10 \mu \mathrm{m}) \text {. } \\
\text { - Bilobate with rounded } \\
\text { lobes and short shaft } \\
\text { (<10 }<\mathrm{m}) \text {. } \\
\text { - Equidimensional bodies } \\
\text { with four lobes }\end{array}$ & $\begin{array}{l}\text { Fredlund and Tieszen } \\
\text { 1994; Pieperno } \\
\text { 2006; Fahmy 2008; } \\
\text { Rossouw 2009; } \\
\text { Neumann et al. 2009; } \\
\text { Mercader et al.2010; } \\
\text { Novello et al., 2012. }\end{array}$ \\
\hline Chloridoideae & $\begin{array}{l}\text { - Saddle } \\
\text { (Figure 4n). } \\
\text { - Saddle squat. }\end{array}$ & $\begin{array}{l}\text { - Saddle bodies with two } \\
\text { opposite convex edges } \\
\text { and two opposite concave } \\
\text { edges in top view. } \\
\text { - Saddle with side notches } \\
\text { and a much longer axis } \\
\text { than its tangential line. }\end{array}$ & $\begin{array}{l}\text { Piperno 2006; } \\
\text { Rossouw 2009; } \\
\text { Neumann et al. 2009; } \\
\text { Novello et al. 2012; } \\
\text { Mercader et al., 2010. }\end{array}$ \\
\hline $\begin{array}{l}\text { Undifferentiated } \\
\text { grasses }\end{array}$ & $\begin{array}{l}\text { - Bulliforms } \\
\text { (Figure 4k). }\end{array}$ & $\begin{array}{l}\text { - Parallelepipedal } \\
\text { bulliform cells. }\end{array}$ & $\begin{array}{l}\text { Madella et al. 2005; } \\
\text { Neumann et al. } 2009 \text {; } \\
\text { Novello et al., } 2012 .\end{array}$ \\
\hline Palm trees & $\begin{array}{l}\text { - Globular echinate } \\
\text { (palm type) } \\
\text { (Figure 4c). }\end{array}$ & $\begin{array}{l}\text { - Globular echinate, with } \\
\text { defined spines. }\end{array}$ & $\begin{array}{l}\text { Albert et al. 2006; } \\
\text { 2009; Piperno 2006; } \\
\text { Barboni et al., 2007; } \\
2009 .\end{array}$ \\
\hline $\begin{array}{l}\text { Woody taxa } \\
\text { (Dicot) }\end{array}$ & $\begin{array}{l}\text { - Globular granulate } \\
\text { (Figure 4a). } \\
\text { - Globular verrucate } \\
\text { (Figure 4d). } \\
\text { - Tracheids } \\
\text { (Figure 4g). } \\
\text { - Sclereids } \\
\text { (Figure 4e). }\end{array}$ & $\begin{array}{l}\text { - Spheroid/ spherical with } \\
\text { fine knobs or knots, } \\
\text { grainy. } \\
\text { - Spheroid/spherical with } \\
\text { irregularly shaped } \\
\text { wart-like processes. } \\
\text { - Tracheids. } \\
\text { - Silicified elongate to } \\
\text { slightly curved } \\
\text { treachery tissue. }\end{array}$ & $\begin{array}{l}\text { Strömberg 2004; } \\
\text { Madella et al. 2005; } \\
\text { Albert et al. 2005; } \\
\text { Piperno 2006; } \\
\text { Neumann et al. } 2009 .\end{array}$ \\
\hline $\begin{array}{l}\text { Herbaceous } \\
\text { taxa }\end{array}$ & $\begin{array}{l}\text { - Globular psilate, } \\
\text { elongate spiny. }\end{array}$ & $\begin{array}{l}\text { - Spheroid/spherical with } \\
\text { smooth to sub-smooth } \\
\text { surface. }\end{array}$ & $\begin{array}{l}\text { Madella et al. 2005; } \\
\text { Piperno 2006; } \\
\text { Neumann et al., } 2009 .\end{array}$ \\
\hline Cyperaceae & $\begin{array}{l}\text { - Achene types, hat } \\
\text { shapes } \\
\text { (Figure 4h). }\end{array}$ & $\begin{array}{l}\text { - Pentagonal or hexagonal } \\
\text { shape, with psilate surface } \\
\text { and a central rounded } \\
\text { cone. }\end{array}$ & $\begin{array}{l}\text { Ollendorf 1992; } \\
\text { Piperno 2006; } \\
\text { Neumann et al., } 2009 .\end{array}$ \\
\hline
\end{tabular}




\subsubsection{Data analyses}

Morphotypes with $>2 \%$ occurrence were plotted against sampling depths and age estimates using TILIA software (Grimm 2007). The zonation is determined statistically by constrained incremental sum-of-squares analysis (CONISS), a component of the TILIA and TILIA GRAPH software (Grimm 2007), based on sequential samples that coincide with the geological age bracket from which they were sampled.

We calculated three phytolith indices: (i) tree cover density (D/P) to distinguish grassland versus wooded vegetation, whereby a high $\mathrm{D} / \mathrm{P}$ ratio indicates woody vegetation, and a low $\mathrm{D} / \mathrm{P}$ ratio indicates open grassland, (ii) climate index $\left(\left(\mathrm{I}_{\mathrm{C}}\right)\right.$ to estimate the temperature gradient, whereby high $\mathrm{I}_{\mathrm{C}}$ indicates cool climates, and low $\mathrm{I}_{\mathrm{C}}$ indicates warmer climates, and (iii) aridity index (Iph) to estimate aridity-humidity gradient across time (Alexandre et al. 1997; DiesterHaas et al. 1973), whereby a high Iph indicates arid while low Iph indicates moist-conditions (Alexandre and Bremond 2009; Bremond et al. 2005a, Bremond et al. 2005b; 2008; Neumann et al., 2009).

The $\mathrm{D} / \mathrm{P}$ index is calculated as the ratio of diagnostic woody dicotyledons morphotypes (globular granulate/ornate) versus diagnostic grass short cell phytoliths (GSCPs) (saddles+bilobates+crosses+polylobates+trapeziform rondels) (Alexandre et al. 1997; Bremond et al. 2005b; Bremond et al. 2008; Neumann et al. 2009). The Iph index is calculated as the ratio of Chloridoideae (saddle) versus the sum of Chloridoideae (saddle) and Panicoideae (cross + bilobates + polylobates) (Bremond et al. 2005b; Neumann et al. 2009). The $\mathrm{I}_{\mathrm{C}}$ index is the ratio of Pooideae $\mathrm{C}_{3}$ grasses (trapeziform and keeled rondels) versus $\mathrm{C}_{4}$ Panicoideae and Chloridoideae grasses (saddles + bilobates + crosses + polylobates + trapeziform) (Bremond et al. 2008).

\subsection{RESULTS}

\subsubsection{Temporal changes}

Temporal variation in phytolith assemblages are presented in summary diagrams which shows changes in the proportion of the various morphotypes (Figure 5). Five main taxonomic categories are identified and classified into: (i) $\mathrm{C}_{3}$ grasses (Pooideae), (ii) $\mathrm{C}_{4}$ grasses (Panicoideae, Chloridoideae and Aristidoideae), (iii) other grasses (undifferentiated grasses), (iv) tree-shrub-herbs (woody and other taxa), and (v) aquatic taxa (palms and sedges).

A total of 18,679 phytoliths were assigned to 41 different morphotypes . Concentrations of phytoliths averaged 747 per sample, of which around $61 \%$ were grasses, $12 \%$ trees and shrubs, while palms and sedges morphotypes accounted for $2 \%$ each. Non-diagnostic morphotypes accounted for $0.01 \%$ only. Of the 11,400 grass phytoliths $91 \%$ are diagnostic. Grass phytoliths were the most prominent component in all samples except for three from the Olorgesailie Fm. (R9, R16 and R17) which were dominated by trees/shrubs morphotypes. Variations in the phytolith assemblage where clustered into zones using CONNISS; these vegetation based divisions were found to correspond closely with the chronostratigraphic units (Figure 5).

\subsubsection{Upper Olorgesailie formation zone (c. $670 \mathrm{ka}$ to $500 \mathrm{ka}$ )}

The phytolith assemblages in the Upper Olorgesailie Fm. zone show greater abundance of trees/shrubs morphotypes relative to the grass morphotypes (Figure 5). $\mathrm{C}_{4}$ Aristidoideae morphotypes are consistently low in this unit. Palm and sedge phytoliths are present in moderate abundance in nearly all of the six samples from this zone. Phytolith indices, $\mathrm{I}_{\mathrm{C}}, \mathrm{Iph}$ and $\mathrm{D} / \mathrm{P}$ in the Olorgesailie Fm zone are as follows:- mean and max. respectively $\mathrm{I}_{\mathrm{C}}(0.3,0.6)$, Iph $(0.5,0.7)$ and $\mathrm{D} / \mathrm{P}(0.4,1.0)$. The $\mathrm{I}_{C}$ maximum is recorded in the sample prior to $650 \mathrm{ka}$ while Iph and $\mathrm{D} / \mathrm{P}$ maxima are recorded around $650 \mathrm{ka}$ (Figure 6). 


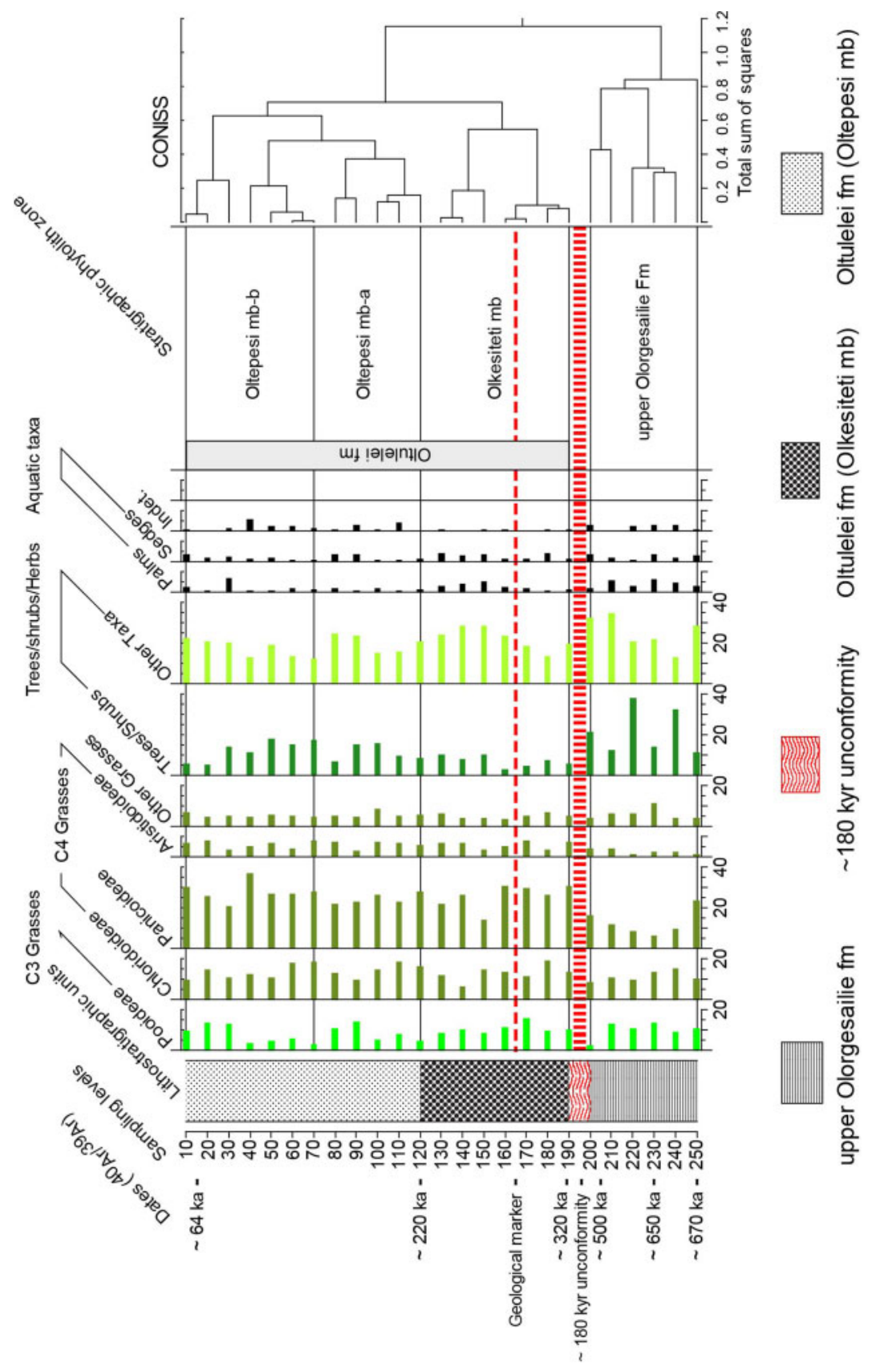

Figure 5. Phytolith relative abundance plotted against sample levels $10-250$, representing the combined stratigraphic sequence through the Oltulelei and upper Olorgesailie formations. Note that actual sample intervals are variable in thickness but are equalized for this diagram.. See text for explanation of phytolith zones. CONISS = constrained incremental sum-of-squares analysis, a component of the TILIA and TILIA GRAPH software (Grimm 2007). 


\section{Temporal phytolith indices}

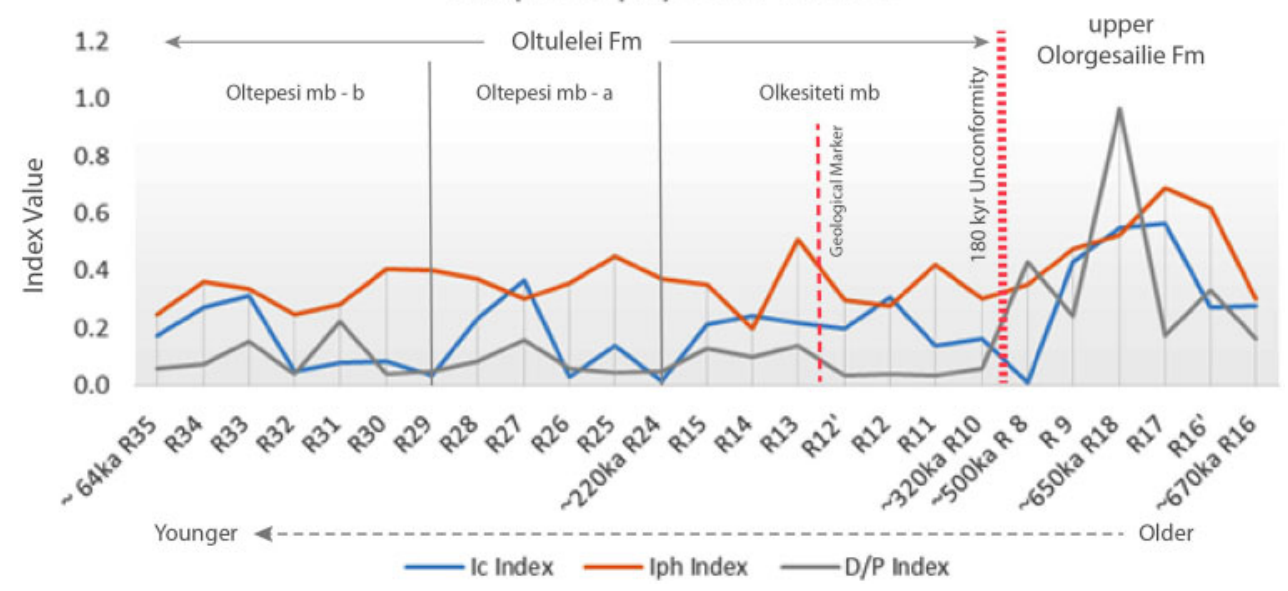

Figure 6. Phytolith indices plotted against samples. Climate index $\left(\mathrm{I}_{\mathrm{C}}\right)$ increases with cool conditions, Aridity index (Iph) increases with low precipitation and Tree cover density (D/P) increases with more wooded vegetation structure.

Graph plotted with older to younger going from right to left. Geological markers indicate with dotted red lines.

\subsubsection{Olkesiteti mb zone (c. 320 ka to $220 \mathrm{ka}$ )}

This zone is separated from the underlying Olorgesailie Fm. zone by the $c .180,000$ year unconformity (Behrensmeyer et al. 2002; 2018). Phytolith assemblages are mostly dominated by grasses, especially $\mathrm{C}_{4}$ Panicoideae. The Olkesiteti mb zone represents phytolith data for samples R10 to R24 and marks the beginning of reduced frequencies of trees/shrubs phytoliths with increased GSCPs dominated by $\mathrm{C}_{4}$ Panicoideae morphotypes (Figure 5). Through the zone there is a significant increase in palm phytoliths, which had virtually disappeared following the unconformity. Interestingly, this variation, along with increased GSCPs and reduction of trees/shrubs morphotypes, appears to correspond with the geological marker in the unit. Phytolith preservation is good, as indicated by the low count in the indeterminate category. Phytolith indices, $\mathrm{I}_{\mathrm{C}}$, Iph and $\mathrm{D} / \mathrm{P}$ in the zone are as follows:- mean and max. respectively $\mathrm{I}_{\mathrm{C}}(0.2,0.3), \mathrm{Iph}(0.3,0.5)$ and $\mathrm{D} / \mathrm{P}$ $(0.1,0.1)$ (Figure 6).

\subsubsection{Oltepesi mb zone (c. $220 \mathrm{ka}$ to $64 \mathrm{ka}$ )}

The Oltepesi mb zone is marked by increased GSCPs, especially $\mathrm{C}_{4}$ Panicoideae morphotypes, similar to the Olkesiteti mb zone. However, in this zone a slight increase in trees/shrubs morphotypes is evident, exceeding $15 \%$ in most of the samples. The zone is further sub-divided into two sub-zones, viz. Oltepesi mb zone-a and -b following the CONNISS clustering.

a) Sub-zone Oltepesi mb-a exhibits a continuation of $\mathrm{C}_{4}$ Panicoideae and $\mathrm{C}_{4}$ Chloridoideae grass dominance. Palm phytoliths are rare but an increase in tree/shrub phytoliths $>15 \%$ occurs, especially in samples R26 (100) and R27 (90) (Figure 5).

b) Sub-zone Oltepesi mb-b is characterized by trees/shrubs and $\mathrm{C}_{4}$ Panicoideae grasses with the exception of sample R33 (30), which has a high occurrence of $\mathrm{C}_{3}$ Pooideae grasses, while both $\mathrm{C}_{4}$ Panicoideae and Chloridoideae grasses are relatively low in this sub-zone. Phytolith indices, $\mathrm{I}_{\mathrm{C}}$, Iph and $\mathrm{D} / \mathrm{P}$ in the entire zone are as follows:- mean and max. respectively $\mathrm{I}_{\mathrm{C}}(0.1,0.4)$, Iph $(0.3,0.4)$ and $\mathrm{D} / \mathrm{P}(0.1,0.2)$ (Figure 6). 


\subsubsection{Spatial variation}

We documented variations in phytolith assemblages across the three localities sampled from three geological sections, OLT05-02, B05-04 and G08-01 (Figure 2). The distance between Localities OLT and B is c. $2.2 \mathrm{~km}$ and between B and $\mathrm{G} c .2 .5 \mathrm{~km}$, in the east-west direction (Behrensmeyer et al. 2018). Summary phytolith diagrams (Figure 7) show percentage occurrence of selected morphotypes identified and classified by taxonomic affiliation, which are then grouped into five major categories: (i) $\mathrm{C}_{3}$ grasses, (ii) $\mathrm{C}_{4}$ grasses, (iii) woody and herbaceous taxa, (iv) Other taxa, and (v) riparian/aquatic taxa. The percentages are plotted for each sample for the period between c. $320 \mathrm{ka}$ and c. $220 \mathrm{ka}$ (Figure 7).

OLT05-02 samples, which is farthest east, show two major clusters (Figure 7). The lower three samples are characterized by low occurrence of $\mathrm{C}_{4}$ Chloridoideae grasses $(<10 \%)$ and relatively higher occurrence of trees/shrubs and dicots phytoliths at $>20 \%$. The upper cluster is dominated by grass morphotypes, derived especially from $\mathrm{C}_{4}$ Panicoideae and Chloridoideae. Chloridoideae morphotypes increase to more than $10 \%$ in this cluster. $\mathrm{C}_{3}$ Pooideae morphotypes are more or less consistent across all six samples. Palm and sedge phytoliths are rare in all samples. Phytolith indices, mean and max. respectively for the OLT05-02 samples are as follows: $\mathrm{I}_{\mathrm{C}}(0.7$, max. 1.6), Iph $(0.3,0.4)$ and $\mathrm{D} / \mathrm{P}(0.1,2.1)$ (Figure 8$)$.

B05-04 samples are similar except for sample number R19 (c. $320 \mathrm{ka})$, which is dominated by tree/shrub morphotypes with a high occurrence of $60 \%$ dropping sharply to $20 \%$ or less in the subsequent samples towards $c .220 \mathrm{ka}$. Also present in low frequencies in this sample (R-19) are palm phytoliths, which are absent in the other samples in this section. Sedges are present in low percentages only across all five samples. Phytolith indices, mean and max. respectively for the B05-04 samples are as follows: $\mathrm{I}_{\mathrm{C}}(0.5$, max. 0.6), Iph $(0.5,0.6)$ and $\mathrm{D} / \mathrm{P}(0.5,0.6)$ (Figure 8).

G08-01 samples from the site situated farthest to the west, are divided into two major clusters that correspond with the red soil zone, which is geologically significant as the oldest unit of the Oltulelei Fm. in this locality (Behrensmeyer, et al. 2018) (Figure 7); the top of the red soil forms the 'geological marker' indicated in Figure 5. The lower cluster consists of samples R35, R36 and R37. Sample R37 differs from the rest in that it has the highest occurrence grass morphotypes coupled with lowest occurrence of tree/shrub morphotypes (10\%). The upper cluster (R39, R41, and R42) is characterized by the presence of phytolith morphotypes from all categories. Palm phytoliths are present in significant frequencies except for R38 (c. $320 \mathrm{ka}$ ), which is notable for its high proportion of dicots, trees and shrubs.

We calculated phytolith indices for only five samples because it was not possible to do so for sample $\mathrm{R} 38 ; \mathrm{C}_{4}$ grass morphotypes in this sample were absent, and extremely low $\mathrm{C}_{3}$ Pooideae and tree/shrub morphotypes did not permit calculation of indices. Phytolith indices, mean and max. respectively for the B05-04 samples are as follows: $\mathrm{I}_{\mathrm{C}}(0.6$, max. 0.8$)$, Iph $(0.3,0.5)$ and $\mathrm{D} / \mathrm{P}(2.3,7.5)$ (Figure 8).

\subsection{DISCUSSION}

\subsubsection{Temporal vegetation change in the Olorgesailie basin (c. $670 \mathrm{ka}$ to $64 \mathrm{ka})$}

Temporal changes in the vegetation cover and structure correspond to a relatively stable tectonic intervals in the basin around $670 \mathrm{ka}$ to $500 \mathrm{ka}$, when vegetation structure was characterized by wooded grasslands as indicated by a higher $\mathrm{D} / \mathrm{P}$ index $(>0.5)$. The landscapes during this time window were characterized by riparian habitats and fresh water resources indicated by palms and sedges (Albert et al. 2009; Ashley et al. 2010 a, b; Bamford et al. 2006). Iph index suggests moderately moist conditions in the upper Olorgesailie Formation. After the $c .180,000$ years unconformity, vegetation cover transitioned to $\mathrm{C}_{4}$ Panicoideae dominated grasslands, that 


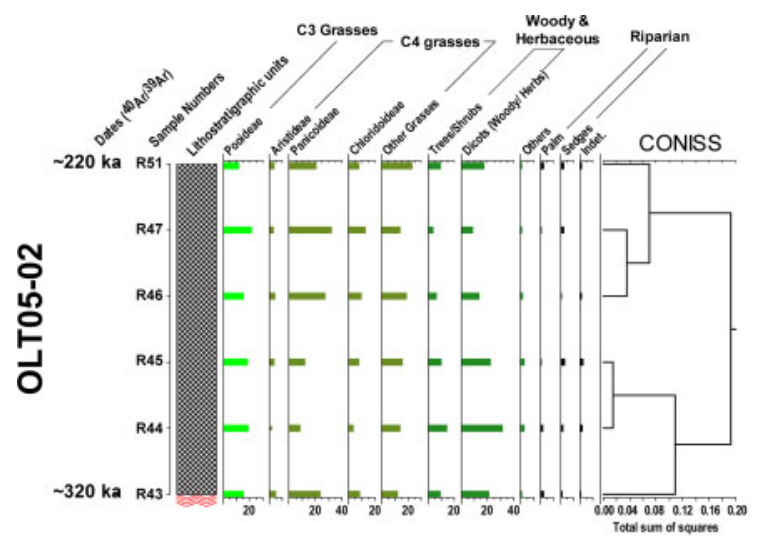

\section{East}
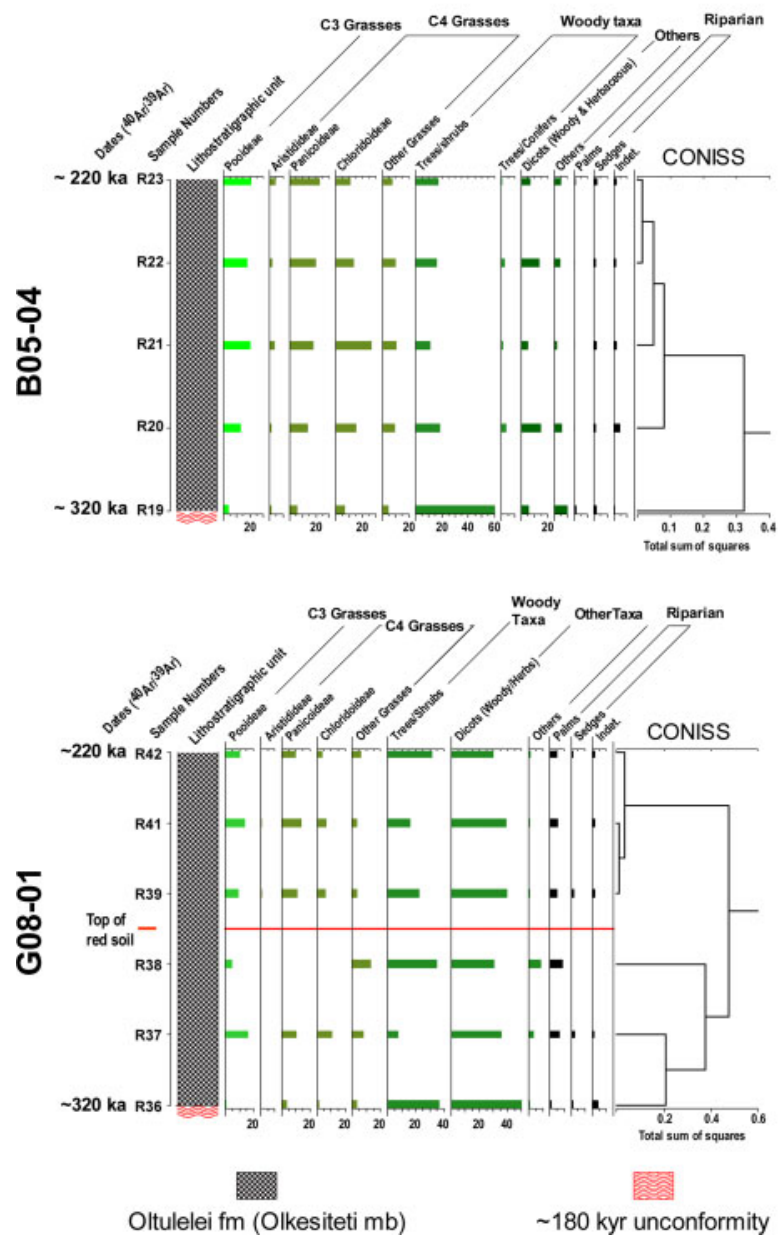

Figure 7. Phytolith relative abundance plotted against samples from the same $100 \mathrm{ka}$ time interval for Localities OLT, $\mathrm{B}$ and $\mathrm{G}$, which shows kilometre-scale landscape variability in local vegetation across the Olorgesailie basin. In G08-01, 'Top of red soil' = 'Geological Marker' in Figures 5 and 6. See text and caption to Figure 5 for further information. 

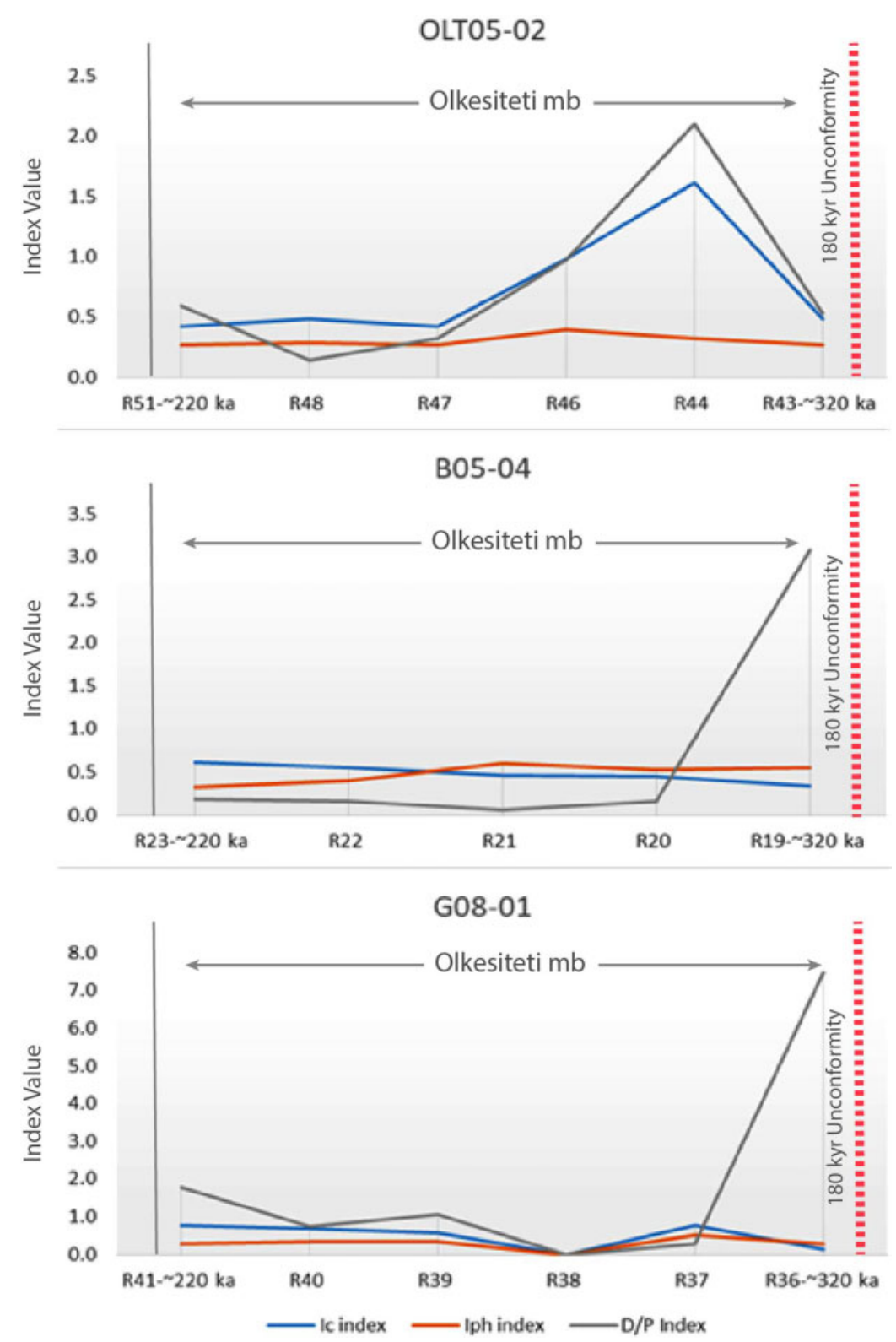

Figure 8. Olorgesailie phytolith indices plotted against samples for localities OLT, B and G. Graphs plotted with older to younger going from right to left. Climate index $\left(\mathrm{I}_{\mathrm{C}}\right)$ increases with cool conditions, Aridity index (Iph) increases with low precipitation and Tree cover density $(\mathrm{D} / \mathrm{P})$ increases with more wooded vegetation structure. Geographically, OLT05-02 is farthest east, B05-04 in the middle, and G08-01 is farthest west (Figure 2).

fluctuates subtly through to $c .64 \mathrm{ka}$. $\mathrm{I}_{\mathrm{C}}$ and Iph indices suggest warm and moist conditions. Vegetation cover between $c .220 \mathrm{ka}$ and $64 \mathrm{ka}$, was stable and dominated by C4 Panicoideae grasslands with low proportions of woody elements. Wetlands were present through to $c .220 \mathrm{ka}$. As mentioned earlier, variation corresponds to lithostratigraphic units. 


\subsubsection{Vegetation heterogeneity across the Olorgesailie basin (c. 320 ka to $220 \mathrm{ka})$}

Vegetation heterogeneity existed across the landscapes of the Olorgesailie basin between $c .320 \mathrm{ka}$ and c. $220 \mathrm{ka}$. Within locality OLT, toward the eastern part of the rift basin (Figure 2), vegetation cover was initially dominated by woody elements that shifted towards $\mathrm{C}_{4}$ Panicoideae grasslands. Palms and sedges were rarely present. Locality B, near the northern shoulder of Mt. Olorgesailie, was also dominated by $\mathrm{C}_{4}$ Panicoideae grasslands except around $c .320 \mathrm{ka}$, which was marked by high dominance in woody vegetation. Sedges were rarely present and palms completely absent. Locality $\mathrm{G}$ on the western side of Mt. Olorgesailie was consistently dominated by woody and dicot vegetation, with abundant palms. $\mathrm{C}_{3}$ Pooideae grasses across the three localities follows an east-west declining trend and are more prominent across the eastern and central localities (B and OLT) than at Locality G. This suggests that topographic complexity in the basin also influenced vegetation variation across the palaeolandscapes at least $5 \mathrm{~km}$ distance. Mt. Olorgesailie, which is today characterized by $C_{3}$ vegetation, likely also was a source of the $C_{3}$ Pooideae phytoliths input into the basin during the Oltulelei Fm. The evidence overall indicates considerable spatial variation in vegetation structure across the basin during the period of sedimentation.

\subsubsection{Palaeoanthropological significance of vegetation data}

The phytolith data presented here represent temporal resolution of $10^{4-5}$ years over a total interval of $c$. 600,000 years and are currently the only comprehensive outcrop-based data in East Africa for inferring vegetation during the Middle to Late Pleistocene transition in early hominin technology from Acheulean to Middle Stone Age (MSA) tools, by c. 350 ka to $320 \mathrm{ka}$ (Brooks et al. 2018; Potts et al. 2018). Before the $c$. 180,000-year erosional phase, the vegetation structure associated with the late Acheulean technology at Olorgesailie was more wooded, and included wetlands/riparian resources, contrasting with the vegetation structure associated with MSA technology, which was dominated by warm and moist-adapted $\mathrm{C}_{4}$ Panicoideae grasslands. This corresponds with a marked change in the geology and lithology of the basin between $c .500$ and $320 \mathrm{ka}$, which exhibited a shift to a landscape with fluvial channels, flood plains and spring deposits (Behrensmeyer et al. 2018; Potts et al. 2018). The vegetation change was accompanied by large mammal turnover, evidenced by the paleontological evidence in the southern Kenyan rift (Potts et al. 2018). Herbivores may have played a significant role in engineering the vegetation structure as it shifted from more wooded to open grasslands in the basin (Potts et al. 2020). These dynamics could have influenced human adaptive strategies that led to new technological innovations (Brooks et al. 2018; Potts et al. 2020).

Vegetation heterogeneity, specifically the occurrence of a mosaic of riparian, grasslands and woodland patches in the time interval between $320 \mathrm{ka}$ and $220 \mathrm{ka}$, suggests a variety of habitats that availed key resources for hominins and offered attractive spots for food resources. Such mixed habitats have been inferred at other prehistoric sites such as Olduvai and Awash and proved to be of palaeoanthropological significance (Albert et al. 2009; Ashley et al. 2010; Bamford et al. 2006; Barboni et al. 1999).

\subsection{CONCLUSIONS}

Phytolith data show that vegetation structure and cover in the Olorgesailie basin was more wooded prior (c. $670 \mathrm{ka}$ to $500 \mathrm{ka}$ ) to the $c .180,000$ year unconformity. Riparian habitats were present with subtle variation between palaeolandscapes. Trees and shrubs fluctuated between landscapes while grasslands remained stable. From 320 ka to $64 \mathrm{ka}$ vegetation cover shifted to grasslands dominated by $\mathrm{C}_{4}$ Panicoideae with some riparian habitats. Between $c$. $320 \mathrm{ka}$ and $220 \mathrm{ka}$, our evidence shows that relatively adjacent habitats in the basin included a diversity of open grasslands, woodland, and riparian elements. 
Phytolith data from this study assist in developing an understanding of local palaeoenvironments with which early hominins interacted during the Pleistocene (c. $670 \mathrm{ka}$ to $64 \mathrm{ka}$ ). The data suggest that late Acheulean technology in the southern Kenya rift was associated with more woody vegetation structure than early MSA technology, which appears to have coincided with grassy landscapes in the Olorgesailie basin. This technological transition at Olorgesailie represents the oldest example currently known of the replacement of the Acheulean by the MSA (Brooks et al. 2018; Deino et al. 2018). We propose that this important transition may have occurred in response to changing vegetation and food resources available to the fauna, and may help to explain the replacement of large-bodied by smaller-bodied herbivores that were increasingly reliant on mixed vegetation diets (Potts et al. 2020). The varied habitats present in the basin offered critical resources such as fresh water and forage that would have sustained hominins and other animals.

In conclusion, vegetation dynamics in Olorgesailie during the Pleistocene reflected responses to both precipitation variability and tectonic processes. The vegetation data presented here are significant in that they are directly extracted from and related to fossil- and artifactbearing outcrops and shed new light on the evidence for interactions between hominins and other faunal and floral communities in the basin. We postulate that such interactions likely played a critical role in shaping hominin behavior and technological innovations.

\section{ACKNOWLEDGEMENTS}

Our sincere gratitude goes to the following institutions, National Museums of Kenya (NMK), University of Cape Town, Smithsonian Institution, and University of Calgary. Support from the Peter Buck Fund for Human Origins Research (Smithsonian) is much appreciated acknowledged. We also thank Alan Deino for his long-term collaboration on the geological dates discussed in this paper; Jennifer Clark for her assistance in all the logistics that involved the Smithsonian Institution and for assisting with the figures; Drs. Veronica Muiruri and Stephen Rucina for the technical provisions during analyses at the Palynology and Paleobotany lab, NMK.

\section{REFERENCES}

Albert, R.M., and Weiner, S., 2001, Study of phytoliths in prehistoric ash layers from Kebara and Tabun caves using a quantitative approach. In: Phytolith: Applications in Earth sciences and Human History, edited by Meunier, J.D., Colin, F., (Lisse: A.A Balkema), pp. 251-266.

Albert, R.M., Bamford, M.K. and Cabanes, D., 2006, Taphonomy of Phytolith and macroplants in different soils from Olduvai Gorge (Tanzania) and the application to Plio-Pleistocene Palaeoanthropological samples. Quaternary International 148, pp.78-94, 10.1016/j.quaint. 2005.11.026.

Albert, R.M., Bamford, M.K., and Cabanes, D., 2009, Palaeoecological significance of palms at Olduvai Gorge, Tanzania, based on Phytolith remains. Quaternary International 193, pp. 41-48, 10.1016/j.quaint.2007.06.008.

Alexandre, A. and Brémond, L., 2009, Comment on the Paper in Quaternary International: "Methodological concerns for Analysis of phytolith assemblages: Does count size matter?” (C.A.E. Strömberg). Quaternary International, 193, pp. 141-142, 10.1016/j.quaint. 2008.03.015.

Alexandre, A., Meunier, J.-D., Lézine, A.-M., Vincens, A. and Schwartz, D., 1997, Phytoliths: indicators of grasslands dynamics during the late Holocene in intertropical Africa. Palaeogeography, Palaeoclimatology, Palaeoecology 136, pp. 213-229, 10.1016/S00310182(97)00089-8. 
Asani, G.C., and Kinuthia, J.H., 1979, Diurnal variation of Precipitations in East Africa- Nairobi, Kenya. Metrological Department Research Report, 8, pp.1-58.

Ashley, G.M., Barboni, D., Dominguez-Rodrigo, M., Bunn, H.T., Mabulla, A.Z.P., Diez-Martin, F., Barba, R. and Baquedano, E., 2010a, A Spring and wooded habitats at FLK Zinj and their relevance to origins of Human behaviour. Quaternary Research, 74(3), pp. 304-314, 10.1016/j.yqres.2010.07.015.

Ashley, G.M., Barboni, D., Dominguez-Rodrigo, M., Bunn, H.T., Mabulla, A.Z.P., Diez-Martin, F., Barba, R., 2010b, Paleoenviromental and Paleoecological reconstruction of a fresh water oasis in Savannah grasslands at FLK North, Olduvai Gorge Tanzania. Quaternary Research, 74(3), pp. 333-343, 10.1016/j.yqres.2010.08.006.

Baker, B.H., 1958, Geology of the Magadi Area: Geological Survey of Kenya, Report Number 42, (Nairobi: Government Printer).

Baker, B.H. and Mitchell, J.G., 1976, Volcanic stratigraphy and geochronology of the KedongOlorgesailie area and the evolution of the southern Kenya rift Valley. Journal of the Geological Society of London,132, pp. 467-484, 10.1144/gsjgs.132.5.0467.

Bamford, M.K., Albert, R.M., and Cabanes, D., 2006, Plio-Pleistocene macroplant fossil remains and phytoliths from Lowermost Bed II in the eastern palaeolake margin of Olduvai Gorge, Tanzania. Quaternary International, 148, pp. 95-112, 10.1016/j.quaint.2005.11.027.

Barboni, D. and Bremond, L., 2009 Phytoliths of East African grasses: An assessment of their environmental and taxonomic significance based on floristic data. Review of Palaeobotany and Palynology, 158, pp. 29-41, 10.1016/j.revpalbo.2009.07.002.

Barboni, D., Bonnefille, R., Alexandre, A. and Meunier, J. D., 1999, Phytoliths as paleoenvironmental indicators, West Side Awash Valley, Ethiopia. Palaeogeography, Palaeoclimatology, Palaeoclimatology, 152, pp. 87-100, 10.1016/S0031-0182(99)00045-0.

Barboni, D., Bremond, L. and Bonnefille, R., 2007, Comparative study of modern phytolith assemblages from inter-tropical Africa. Palaeogeography, Palaeoclimatology, Palaeoclimatology, 246, pp. 454-470, 10.1016/j.palaeo.2006.10.012.

Barboni, D., Ashley, G.M., Dominguez-Rodrigo, M. and Bunn, H.T., Mabulla, A. Z.P and Baquedano, E., 2010, Phytoliths infer locally dense and heterogeneous paleovegetation at FLK North and surrounding localities during upper Bed I time, Olduvai Gorge, Tanzania. Quaternary Research, 74, pp. 344-354, 10.1016/j.yqres.2010.09.005.

Behrensmeyer, A.K., Potts, R., Deino, A. and Ditchfield, P., 2002, Olorgesailie, Kenya: a million years in the life of a rift basin. In Sedimentation in Continental Rifts, SEPM Special. Publication 73, edited by Renault, R.W. and Ashley, G., pp. 99-106.

Behrensmeyer, A.K., Potts, R., and Deino, A., 2018, The Oltulelei Formation of the southern Kenyan Rift Valley: A chronicle of rapid landscape transformation over the last $500 \mathrm{ky}$. Geological Society of America Bulletin, 130, pp.1474-1492, 10.1130/B31853.1.

Bremond, L., Alexandre, A., Hély, C., and Guiot, J., 2005a, A Phytolith index as a proxy of tree cover density in tropical areas: calibration with Leaf Area Index along a forestsavanna transect in southeastern Cameroon. Global and Planetary Change, 45(4), pp. 277-293, 10.1016/j.gloplacha.2004.09.002.

Bremond, L., Alexandre, A., Hély, C., and Guiot, J., 2005b, Grass water stress estimated from phytoliths in West Africa. Journal of Biogeography, 32(2), pp. 311-327, 10.1111/j.13652699.2004.01162.x.

Bremond, L., Alexandre, A., Wooller, M. J., Hély, C., Williamson, D., Schäfer. P. A., Majule, A. and Guiot, J., 2008, Phytolith indices as proxies of grass subfamilies on the East African tropical mountains. Global and Planetary Change, 61, pp. 209-224, 10.1016/j.gloplacha.2007.08.016.

Brooks, A.S., Yellen, J.E., Potts, R., Behrensmeyer, A.K., Deino, A.L., Leslie, D.E., Ambrose, S.H., Ferguson, J.R., d'Errico, F., and Zipkin, A.M., 2018, Long-distance stone transport and pigment use in the earliest Middle Stone Age. Science, 360, p. 90-94, 10.1126/ science.aao2646. 
Brown, F., and Feibel, C.S., 1991, Stratigraphy, depositional environments, and palaeogeography of Koobi Fora Formation. In Koobi Fora Research Project, Volume 3, edited by Harris, J.M., (Oxford: Clarendon Press), pp. 1-30.

Cerling, T.E., Levin, N.E., Quade, J., Wynn, J.G., Fix, D.L., Kingstone, J.D., Klein, R.G. and Brown, F.H., 2010, Comment on the Paleoenvironments of Ardipithecus ramidus. Science, 328, pp. 1105, 10.1126/science.1185274.

Cerling, T.E., Wynn, J.G., Andanje, S.A., Bird, M.I., Korir, D.K., Levin, N.E., Mace, W., Macharia, A.N., Quade, J., and Remien, C.H., 2011, Woody cover and hominin environments in the past 6 million years. Nature, 476, pp. 51-56, 10.1038/nature10306.

Damnati, B. and Taieb, M., 1995, Solar and ENSO signatures in laminated deposits from lake Magadi (Kenya) during the Pleistocene/ Holocene transition. Journal of African Earth Sciences, 21(3), pp. 373-382, 10.1016/0899-5362(95)00094-A.

Deino, A., and Potts, R., 1990, Single-crystal ${ }^{40} \mathrm{Ar} /{ }^{39} \mathrm{Ar}$ dating of Olorgesailie Formation, southern Kenya Rift. Journal of Geophysical Research, 95, pp. 8453-8470, 10.1029/ JB095iB06p08453.

Deino, A. and Potts, R., 1992, Age-probability spectra for examination of single crystal ${ }^{40} \mathrm{Ar} /{ }^{39} \mathrm{Ar}$ dating results: examples from Olorgesailie, southern Kenya rift. Quaternary International, 13-14, pp. 47-53, 10.1016/1040-6182(92)90009-Q.

Deino, A., Dommain, R., Keller, C.B., Potts, R., Behrensmeyer, A.K., Beverly, E.J., King, J., Heil, C.W., Stockhecke, M., and Brown, E.T., 2019, Chronostratigraphic model of a highresolution drill core record of the past million years from the Koora Basin, south Kenya Rift: Overcoming the difficulties of variable sedimentation rate and hiatuses. Quaternary Science Reviews, 215, pp. 213-231, 10.1016/j.quascirev.2019.05.009.

deMenocal, P., 1995, Plio-Pleistocene African Climate. Science, 270, pp. 53-59, 10.1126/science.270.5233.53.

deMenocal, P., 2004, African Climate Change and Faunal evolution during the PliocenePleistocene. Earth and Planetary Science Letters, 220, pp. 3-24, 10.1016/S0012821X(04)00003-2.

Esteban, I., Vlok, J., Kotina, E.L., Bamford, M.K., Cowling, R.M., Cabanes, D., Albert, R.M., 2017, Phytoliths in plants from the south coast of the Greater Cape Floristic Region (South Africa). Review of Palaeobotany and Palynology, 245, pp. 69-84, 10.1016/ j.revpalbo.2017.05.001.

Fahmy, A. G., 2008, Diversity of lobate phytoliths in grass leaves from Sahel region, West Tropical Africa: Tribe Paniceae. Plant Systematics and Evolution, 270, pp. 1-23, 10.1007/s00606-007-0597-z.

Feibel, C.S. 1999. Basin Evolution, sedimentary dynamics, and hominid habitats in East Africa. In African Biogeography, Climate Change and Human Evolution, edited by Bromage, T.G. and Schrenk, F. (Oxford: Oxford University Press), pp. 276-281.

Fredlund, G.G. and Tieszen, L.T., 1994, Modern Phytolith Assemblages from the North American Great Plains. Journal of Biogeography, 21, pp. 321-335, 10.2307/2845533.

Fredlund, G.G. and Tieszen, L.T., 1997, Calibrating grass phytolith assemblages in climatic terms: Application to Late Pleistocene assemblage from Kansas and Nebraska. Palaeogeography, Palaeoclimatology, Palaeoecology, 136, pp. 199-211, 10.1016/S0031-0182(97)00040-0.

Grimm, E.C., 2007, TILIA 1.01 and TILIA Graph. Illinois State University, Illinois.

Griffiths, J.F., 1958, Climatic Zones of East Africa. East African Agricultural Journal, 23, pp. 179-185, 10.1080/03670074.1958.11665143.

Griffiths, J.F., 1972, Climates of Africa. World Survey of Climatology, 10, pp. 313-347.

Hills, R.C., 1978, The structure of the Inter-Tropical Convergence Zone in Equatorial Africa and its relationship to East Africa rainfall. Transaction of the Institute of British Geographers, New series 4(3), pp. 329-352, 10.2307/622055. 
Honaine, M.F., Zucol, A.F. and Osterrieth, M.L., 2006, Phytolith Assemblages and Systematic Associations in Grassland species of South-Eastern Pampean Plains, Argentina. Annals of Botany, 98, pp. 1155-1165, 10.1093/aob/mcl207.

Isaac, G.L., 1977, Olorgesailie, Archaeological Studies of a Middle Pleistocene Lake Basin in Kenya, (Chicago: University of Chicago Press).

Isaac, G.L., 1978, The Olorgesailie Formation: stratigraphy, tectonics and the paleogeographic context of the Middle Pleistocene archaeological sites. Geological Society, London, Special Publications, 6, pp. 174-206, 10.1144/GSL.SP.1978.006.01.15.

Kenworthy, J.M., 1966, Temperature conditions in the tropical highland climates in East Africa. The East African Geographical Review, 1966(4), pp. 1-11.

Kinyanjui, R.N., 2012, Phytolith Analysis as a Paleoecological Tool for Reconstructing Mid- Late Pleistocene Environments in the Olorgesailie Basin, Kenya, MSc Dissertation (Environmental and Geographical Sciences Department: University of Cape Town).

Livingstone, D.A. and Mworia-Maitima, J., 1999, Preliminary Report on Preservation Status of Organic Plant Remains in Olorgesailie Basin, Unpublished Report, (Niarobi: National Museums of Kenya).

Madella, M., Alexandre, A., and Ball, T., 2005, International Code for Phytolith Nomenclature 1.0. Annals of Botany, 96, pp. 253-260, 10.1093/aob/mci172.

Mercader, J., Bennett, T., Esselmont, C., Simpson, S. and Walde, D., 2009, Phytoliths in woody plants from the Miombo woodlands of Mozambique. Annals of Botany, 104(1), pp. 91-113, 10.1093/aob/mcp097.

Mercader, J., Astudillo, F., Barkworth, M., Bennett, T., Esselmont, C., Kinyanjui, R., GrossmanLaskin, D., Simpson, S. and Walde, D., 2010, Grass and Sedge phytoliths from Niassa, Mozambique. Journal of Archaeological Science, 37(8): pp. 1953-1967, 10.1016/j.jas.2010.03.001.

Mulholland, S.C. and Rapp, G. Jr., 1992, A morphological classification of grass silica- bodies. In Phytolith Systematic, Emerging Issues: Advances in Archaeological and Museum Science, Volume 1, edited by Rapp, G. Jr. and Mulholland, S.C. (New York: Plenum Press), pp. 65-89.

Mutai, C.C and Ward, M.N., 2000, East African rainfall and the tropical circulation/convection on interseasonal to interannual timescales. Journal of Climate, 13, pp. 3915-3939, 10.1175/15200442(2000)013<3915:EARATT>2.0.CO;2.

Mworia, J., Dallmeijer, A. and Jacobs, B., 1988, Vegetation and modern pollen rain at Olorgesailie, Kenya. Utafiti, 1(1), pp. 1-22.

Neumann, K., Fahmy, A., Lespez. L., Balloche, A., Huysecom, E., 2009, The early Holocene palaeenvironment of Ounjougou (Mali): Phytoliths in multiproxy context. Palaeogeography, Palaeoclimatology, Palaeoecology, 276, pp. 87-106, 10.1016/j.palaeo.2009.03.001.

Neumann, K., Fahmy, A.G., Muller-Scheessel, N., Schmidt, M., 2017, Taxonomic, ecological and palaeoecological significance of leaf phytoliths in West African grasses. Quaternary International, 434, pp. 15-32, 10.1016/j.quaint.2015.11.039.

Nicholson, S.E., 1996, A Review of Climate Dynamics and Climate Variability in eastern Africa. In The Limnology, Climatology and Paleoaclimatology of the East Africa Lakes, edited by Johnson, T.C. and Odada, E.O., (Amsterdam: Gordon and Breach Publishers), pp. 25-56.

Novello, A., Barboni, D., Berti-Equille, L.,Mazur, J-C., Poilecot, P., Vignaud, P., 2012, Phytolith signal of Aquatic plants and soils in Chad, Central Africa. Review of Paleobotany and Palynology, 178, pp. 43-58, 10.1016/j.revpalbo.2012.03.010.

Ollendorf, A.L., 1992, Toward classification scheme of sedge (Cyperaceae) phytoliths. In Phytolith Systematics, Emerging Issues: Advances in Archaeological and Museum Science, Volume 1, edited by Rapp, G. Jr. and Mulholland, S.C. (New York: Plenum Press), pp. 91-111.

Owen, R.B., Potts, R., Behrensmeyer, A.K. and Ditchfield, P., 2008, Diatomaceous sediments and environmental change in the Pleistocene Olorgesailie Formation, southern Kenya Rift Valley. Palaeogeography, Palaeoclimatology, Palaeoclimatology, 269, pp. 17-37, 10.1016/j.palaeo.2008.06.021. 
Piperno, D.R., 1988, Phytolith Analysis: An Archaeological and Geological Perspective. (San Diego: Academic Press).

Piperno, D.R., 1989, The occurrence of phytoliths in reproductive structures of selected tropical angiosperms and their significance in tropical paleoecology, paleoenthnobotany, and systematic. Review of Palaeobotany and Palynology, 61, pp. 147-173, 10.1016/00346667(89)90067-5.

Piperno, D.R., 2006, Phytoliths: A Comprehensive guide for Archaeologists and Paleoecologists, (Oxford: Altamira Press).

Piperno, D.R. and Pearsall, D.M., 1998, The silica bodies of tropical American grasses: Morphology, taxonomy, and implications for grass systematics and fossil phytolith identification. Smithsonian Contributions to Botany, 5, pp. 1-45, 10.5479/si.0081024X.85.

Potts, R., 1989, Olorgesailie: New excavations and findings in Early and Middle Pleistocene contexts, southern Kenya Rift Valley. Journal of Human Evolution, 18, pp. 477-484, 10.1016/0047-2484(89)90076-6.

Potts, R., 1994, Variables versus models in early Pleistocene hominid land use. Journal of Human Evolution, 27, pp. 7-24, 10.1006/jhev.1994.1033.

Potts, R., 1998, Environmental hypotheses of hominin evolution. Yearbook of Physical Anthropology, 41, pp. 93-136, 10.1002/(SICI)1096-8644(1998)107:27+<93::AID-AJPA5>3.0.CO;2-X.

Potts, R., 2001, Mid-Pleistocene environmental change and human evolution. In Human Roots: Africa and Asia in the Middle Pleistocene, edited by Barham, L., Robson-Brown, K., (Bristol: Western Academic Press), pp. 5-21.

Potts, R., 2013, Hominin evolution in settings of strong environmental variability. Quaternary Science Reviews, 73, pp. 1-13, 10.1016/j.quascirev.2013.04.003.

Potts, R., and Deino, A., 1995, Mid-Pleistocene change in large faunas of East Africa. Quaternary Research, 43, pp. 106-113, 10.1006/qres.1995.1010.

Potts, R., and Faith, J.T., 2015, Alternating high and low climate variability: The context of natural selection and speciation in Plio-Pleistocene hominin evolution. Journal of Human Evolution, 87, pp. 5-20, 10.1016/j.jhevol.2015.06.014.

Potts, R., Behrensmeyer, A.K., and Ditchfield, P., 1999, Paleolandscape variation and Early Pleistocene hominid activities: Members 1 and 7, Olorgesailie Formation, Kenya. Journal of Human Evolution, 37, pp. 747-788, 10.1006/jhev.1999.0344.

Potts, R., Behrensmeyer, A.K., Deino, A., Ditchfield, P., and Clark, J., 2004, Small MidPleistocene hominin associated with East African Acheulean technology. Science, 305, pp. 75-78, 10.1126/science.1097661.

Potts, R., Dommain, R., Moerman, J.W., Behrensmeyer, A.K., Deino, A.L., Beverly, E.J., Brown, E.T., Deocampo, D., Kinyanjui, R., Lupien, R.L., Owen, R.B., Rabideaux, N., Riedl, S., Russell, J.M., Stockhecke, M., deMenocal, P., Faith, J.T., Garcin, Y., Noren, A., Scott, J.J., Western, D., Bright, J., Clark, J.B., Cohern, A.S., Heil Jr., C.W., Keller, C.B., King, J., Levin, N., Brady, K., Muiruri, V., Renaut, R., Rucina, S.M., Uno, K., 2020, Increased ecological resource variability during a critical transition in hominin evolution. Science Advances, 6 , 10.1126/sciadv. abc8975, article: eabc8975.

Rapp, G. Jr., and Mulholland, S.C., 1992, Phytolith Systematics: Emerging Issues. Advances in Archaeological and Museums Science. (New York: Plenum Press).

Rossouw, L., 2009, The application of fossil grass-phytolith analysis in the reconstruction of Cainozoic environments in the South African interior, PhD Dissertation, (Faculty of Natural and Agricultural Sciences: University of the Free State, Bloemfontein).

Runge, F. 1999, The opal phytolith inventory of soils in central Africa - quantities, shapes, classifications and spectra. Review of Palaeobotany and Palynology, 107, 1-2, pp. 23-53.

Sansom, H.W., 1954, The climate of East Africa based on Thornthwaite's classification. East Africa Meteorological Department Memoir, 3, pp. 1-49. 
Shackleton, R.M., 1978, A geological map of the Olorgesailie area. In Geological Background to Fossil Man, map insert, edited by Bishop, W.W., (Edinburgh: Scottish Academic Press).

Sikes, N.E., 1994, Early hominid habitat preference in East Africa: Paleosol carbon isotopic evidence. Journal of Human Evolution, 27, pp. 25-45, 10.1006/jhev.1994.1034.

Sikes, N.E., and Ashley, G.M., 2007, Stable isotopes of pedogenic carbonates as indicators of paleoecology in the Plio-Pleistocene (Upper Bed I), western margin of Olduvai Basin, Tanzania. Journal of Human Evolution, 53, pp. 574-594, 10.1016/j.jhevol.2006.12.008.

Sikes, N.E., Potts, R. and Behrensmeyer, A.K., 1999, Early Pleistocene habitat in Member 1 Olorgesailie based on paleosol stable isotopes. Journal of Human Evolution, 37, pp. 721-670, 10.1006/jhev.1999.0343.

Strömberg, C.A.E., 2004, Using Phytolith assemblages to reconstruct the origin and spread of grass-dominated habitats in the Great Plains during the late Eocene to early Miocene. Palaeogeography, Palaeoclimatology, Palaeoecology, 207(3-4), 59-75, 10.1016/j. palaeo.2003.09.028.

Trauth, M.H., Maslin, M., Deino, A., Strecker, M.R., Bergner, A.G.N., and Duhnforth, M., 2007, High-and low-latitude forcing of Plio-Pleistocene East African climate and human evolution. Journal of Human Evolution, 53, pp. 475-486, 10.1016/j.jhevol.2006.12.009.

Twiss, P.C., 1992, Predicted world distribution of C3 and C4 grass phytoliths. In Phytolith Systematics. Emerging Issues: Advances in Archaeological and Museum Science, Volume 1, edited by Rapp. G.J. and Mulholland, S.C., (New York: Plenum Press), pp. 113-128.

Twiss, P.C., Suess, E. and Smith, R.M., 1969, Morphological Classification of Grass Phytoliths. Soil Science Society of America Proceedings, 33, pp. 109-115, 10.2136/sssaj1969. 03615995003300010030x.

White, F., 1983, The Vegetation of Africa. Natural Resources Resarch, UNESCO, 20, pp. 1-356. Wolde Gabriel, G., Ambrose, S.H., Barboni, D., Bonnefille, R., Bremond, L., Currie, B., DeGusta, D., Hart, W.K., Murray, A.M., Renne, P.R. Jolly-Saad, M.C., Stewart, K.M. and White, T.D., 2009, The geological, isotopic, botanical, invertebrate, and lower vertebrate surroundings of Ardipithecus ramidus. Science, 326, article: 65-65e5, 10.1126/science.1175817. 


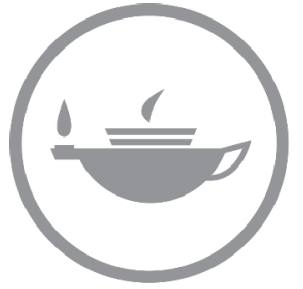

Taylor \& Francis Taylor \& Francis Group http://taylorandfrancis.com 